\title{
Stability of Pantoprazole Sodium in Glass Vials, Polyvinyl Chloride Minibags, and Polypropylene Syringes
}

\author{
Ronald F Donnelly
}

\begin{abstract}
Background: Pantoprazole sodium, a proton-pump inhibitor, is approved for the short-term treatment of several types of ulcer, Zollinger-Ellison syndrome, and gastroesophageal reflux disease.

Objective: To determine the physical compatibility and chemical stability of ethylenediaminetetra-acetic acid (EDTA)-free pantoprazole in glass vials, polypropylene syringes, and polyvinylchloride (PVC) minibags, after storage at $2^{\circ} \mathrm{C}$ to $8^{\circ} \mathrm{C}$ with protection from light or at $20^{\circ} \mathrm{C}$ to $25^{\circ} \mathrm{C}$ with exposure to light.
\end{abstract}

Methods: Solutions of pantoprazole $4 \mathrm{mg} / \mathrm{mL}$ reconstituted in $0.9 \%$ sodium chloride (normal saline [NS]) were stored in glass vials at $20^{\circ} \mathrm{C}$ to $25^{\circ} \mathrm{C}$. Similar solutions were transferred to polypropylene syringes and stored at $2^{\circ} \mathrm{C}$ to $8^{\circ} \mathrm{C}$. Stock solution was further diluted, in $5 \%$ dextrose in water (D5W) or NS, to 0.4 or $0.8 \mathrm{mg} / \mathrm{mL}$, and samples were then packaged in PVC minibags for storage at $2^{\circ} \mathrm{C}$ to $8^{\circ} \mathrm{C}$ or at $20^{\circ} \mathrm{C}$ to $25^{\circ} \mathrm{C}$. Samples collected on days $0,2,3,7,14,21$, and 28 were analyzed in duplicate with a stability-indicating high-performance liquid chromatography assay.

Results: Pantoprazole $4 \mathrm{mg} / \mathrm{mL}$ was stable (i.e., retained at least $90 \%$ of initial concentration) for 3 days when stored in glass vials at $20^{\circ} \mathrm{C}$ to $25^{\circ} \mathrm{C}$ or for 28 days when stored in polypropylene syringes at $2^{\circ} \mathrm{C}$ to $8^{\circ} \mathrm{C}$. Pantoprazole $0.4 \mathrm{mg} / \mathrm{mL}$ diluted in D5W and stored in PVC minibags was stable for 2 days at $20^{\circ} \mathrm{C}$ to $25^{\circ} \mathrm{C}$ or for 14 days at $2^{\circ} \mathrm{C}$ to $8^{\circ} \mathrm{C}$. At $0.8 \mathrm{mg} / \mathrm{mL}$, pantoprazole in D5W was stable for 3 days at $20^{\circ} \mathrm{C}$ to $25^{\circ} \mathrm{C}$ or 28 days at $2^{\circ} \mathrm{C}$ to $8^{\circ} \mathrm{C}$. Pantoprazole diluted to either 0.4 or $0.8 \mathrm{mg} / \mathrm{mL}$ in NS and stored in PVC minibags was stable for 3 days at $20^{\circ} \mathrm{C}$ to $25^{\circ} \mathrm{C}$ or 28 days at $2^{\circ} \mathrm{C}$ to $8^{\circ} \mathrm{C}$.

Conclusions: The present study confirmed or extended previously reported expiry dates for pantoprazole sodium packaged in glass vials, polypropylene syringes, and PVC minibags.

Key words: pantoprazole sodium, injection, dextrose, normal saline, stability, high-performance liquid chromatography, glass vials, polypropylene syringes, polyvinylchloride bags

\section{RÉSUMÉ}

Contexte : L'emploi du pantoprazole sodique, un inhibiteur de la pompe à protons, est approuvé dans le traitement à court terme de divers types d'ulcère, du syndrome de Zollinger-Ellison et du reflux gastro-œsophagien.

Objectif: Déterminer la compatibilité physique et la stabilité chimique de solutions de pantoprazole sodique exemptes d'acide éthylène diamine tétra acétique (EDTA) conditionnées dans des fioles de verre, des seringues de polypropylène et des minisacs de polychlorure de vinyle (PVC) après avoir été entreposées à $2-8^{\circ} \mathrm{C}$ à l'abri de la lumière ou à $20-25^{\circ} \mathrm{C}$ exposées à la lumière.

Méthodes : Des solutions de pantoprazole sodique à $4 \mathrm{mg} / \mathrm{mL}$ reconstitué dans du chlorure de sodium à $0,9 \%$ (solution physiologique salée [SP]) ont été entreposées dans des fioles de verre à $20-25^{\circ} \mathrm{C}$. Des solutions similaires ont été transférées dans des seringues de polypropylène, puis conservées à $2-8^{\circ} \mathrm{C}$. La solution de base a été à nouveau diluée soit dans du dextrose à $5 \%$ dans l'eau (D5E), soit dans une SP, à 0,4 ou à $0,8 \mathrm{mg} / \mathrm{mL}$, et des échantillons ont été conditionnés dans des minisacs de PVC entreposés à $2-8{ }^{\circ} \mathrm{C}$ ou à $20-25^{\circ} \mathrm{C}$. Les échantillons recueillis aux jours $0,2,3,7,14,21$ et 28 ont été analysés en double au moyen d'une épreuve validée par chromatographie liquide haute performance mesurant la stabilité.

Résultats : Les solutions de pantoprazole à $4 \mathrm{mg} / \mathrm{mL}$ sont demeurées stables (conservant au moins $90 \%$ de la concentration initiale) pendant trois jours lorsqu'elles étaient entreposées dans des fioles de verre à $20-25^{\circ} \mathrm{C}$ ou pendant 28 jours lorsquelles étaient conservées dans des seringues de polypropylène à $2-8{ }^{\circ} \mathrm{C}$. Les solutions de pantoprazole à $0,4 \mathrm{mg} / \mathrm{mL}$ diluées dans du D5E et conservées dans des minisacs de PVC sont demeurées stables pendant deux jours à $20-25^{\circ} \mathrm{C}$ ou pendant 14 jours à $2-8^{\circ} \mathrm{C}$. À une concentration de $0,8 \mathrm{mg} / \mathrm{mL}$, les solutions de pantoprazole dans du D5E sont demeurées stables pendant trois jours à $20-25^{\circ} \mathrm{C}$ et pendant 28 jours à $2-8{ }^{\circ} \mathrm{C}$. Les solutions de pantoprazole diluées à une concentration de 0,4 ou de $0,8 \mathrm{mg} / \mathrm{mL}$ dans une SP et conservées dans des minisacs de PVC sont demeurées stables pendant trois jours à $20-25^{\circ} \mathrm{C}$ ou pendant 28 jours à $2-8{ }^{\circ} \mathrm{C}$.

Conclusions : Cette étude confirme ou prolonge les durées de conservation publiées précédemment pour les solutions de pantoprazole sodique conditionnées dans des fioles de verre, des seringues de polypropylène et des minisacs de PVC.

Mots clés : pantoprazole sodique, injection, dextrose, solution physiologique salée, stabilité, chromatographie liquide haute performance, fioles de verre, seringues de polypropylène, sacs de polychlorure de vinyle

[Traduction par l'éditeur] 


\section{INTRODUCTION}

$\mathrm{P}$ antoprazole sodium is a proton-pump inhibitor that can be used for short-term treatment of duodenal ulcer, gastric ulcer, gastroesophageal reflux disease, and pathologic gastrointestinal hypersecretory conditions associated with ZollingerEllison syndrome, and for the prevention of gastrointestinal lesions induced by nonsteroidal anti-inflammatory drugs and duodenal ulcer associated with Helicobacter pylori. For patients who are unable to take medications orally, pantoprazole may be given by direct IV administration or as an IV infusion.

In Canada, pantoprazole sodium for injection is formulated with and without ethylenediaminetetra-acetic acid (EDTA). The 2 formulations have previously been studied by Walker and others ${ }^{1,2}$ and Carpenter and others. ${ }^{3}$ In one study, pantoprazole sodium $4 \mathrm{mg} / \mathrm{mL}$ (with EDTA) packaged in polypropylene syringes was stable for 4 days when stored under refrigeration $\left(3^{\circ} \mathrm{C}\right.$ to $\left.5^{\circ} \mathrm{C}\right)$ or at room temperature $\left(23^{\circ} \mathrm{C}\right.$ to $\left.25^{\circ} \mathrm{C}\right) .{ }^{4} \mathrm{~A}$ search of the literature revealed no information about the stability of pantoprazole sodium $4 \mathrm{mg} / \mathrm{mL}$ packaged in glass vials, and one manufacturer (Sandoz Canada Inc) recommends discarding the unused EDTA-free solution after 6 h. ${ }^{5}$ Another manufacturer of the EDTA-free product (Pharmascience Inc) recommends using the solution within $24 \mathrm{~h}$ of initial puncture of the vial. ${ }^{6}$

Stability studies may have a variety of aims, including reductions in cost, wastage, and workload. At the authors' institution, more than 1000 vials of pantoprazole are used monthly; therefore, extending the expiry date of the various forms of unused solution would be beneficial.

This study was undertaken to generate physical compatibility and chemical stability data for solutions of EDTA-free pantoprazole sodium $4 \mathrm{mg} / \mathrm{mL}$ stored in glass vials at room temperature with exposure to light, with the ultimate goal of extending the expiry timeframe beyond the manufacturer's recommendation of $6 \mathrm{~h}$. In addition, the study was designed to confirm previous stability data (with possible extension of the expiry timeframe) for pantoprazole sodium packaged in polypropylene syringes with storage under refrigeration and protection from light. The study also examined the stability of EDTA-free pantoprazole sodium diluted to 0.4 or $0.8 \mathrm{mg} / \mathrm{mL}$ in either $5 \%$ dextrose in water (D5W) or $0.9 \%$ sodium chloride (normal saline [NS]) and packaged in polyvinylchloride (PVC) bags, with storage for 3 days at room temperature with exposure to light or for 28 days under refrigeration with protection from light.

\section{METHODS}

\section{Sample Preparation}

Stock solutions were prepared by reconstituting a total of 33 commercial vials of EDTA-free pantoprazole sodium for injection (Sandoz Canada Inc, Boucherville, Quebec; lot
AD6461, expiry October 2010) with NS (Baxter Corp, Mississauga, Ontario; lot W9C17A1, expiry September 2010), $10 \mathrm{~mL}$ per vial, according to the manufacturer's instructions. All samples were analyzed before these expiry dates. Three of these vials were stored at room temperature $\left(20^{\circ} \mathrm{C}\right.$ to $\left.25^{\circ} \mathrm{C}\right)$ with exposure to light. Stock solution from 6 vials was combined and then divided among three $20-\mathrm{mL}$ polypropylene syringes (Becton and Dickinson Inc, Deerfield, New Jersey; lot 8353531, expiry December 2013) with subsequent storage under refrigeration $\left(2^{\circ} \mathrm{C}\right.$ to $\left.8^{\circ} \mathrm{C}\right)$ with protection from light. Stock solution was further diluted with either D5W or NS, to either 0.4 or $0.8 \mathrm{mg} / \mathrm{mL}$, and was then transferred to a total of 24 PVC minibags. Three bags of each concentration-diluent combination were stored under refrigeration with protection from light or at room temperature with exposure to light.

\section{Physical Compatibility}

To monitor the solutions for physical compatibility, samples collected at various time points (as described below) were inspected for clarity against a black background and for colour change against a white background using a $4 x$ illuminated magnifying glass. The $\mathrm{pH}$ was determined on each day of analysis with a calibrated $\mathrm{pH}$ meter (Accumet 25, Fisher Scientific Ltd, Nepean, Ontario). The meter was calibrated before determination of $\mathrm{pH}$ using standardized buffers with pH 7 (Fisher Scientific Ltd; lot SC7134746, expiry May 31, 2009) and pH 10 (Fisher Scientific Ltd; lot 082707, expiry May 2010).

\section{Chemical Stability High-Performance Liquid Chromatography System}

The mobile phase for the high-performance liquid chromatography (HPLC) system was similar to that described by Walker and others ${ }^{1}$ but was modified to contain 35\% acetonitrile (instead of $40 \%$ ) with $65 \%$ phosphate buffer $\mathrm{pH}$ 7.1. The phosphate buffer was prepared from $0.05 \mathrm{~mol} / \mathrm{L}$ sodium phosphate (dibasic) USP (Fisher Scientific Ltd; lot 974557) in HPLC-grade water. The $\mathrm{pH}$ of the final mixture was adjusted to 7.1 with concentrated (85\%) HPLC-grade phosphoric acid (Fisher Scientific Ltd; lot 082037). The solid phase for the HPLC system was a C18 5- $\mu \mathrm{m}, 4.6 \times 250 \mathrm{~mm}$ column (Luna, Phenomenex Inc, Torrance, California; lot 441292-2). A flow rate of $1 \mathrm{~mL} / \mathrm{min}$ was delivered with an isocratic delivery pump (model LC-10AS, Shimadzu Corporation, Kyoto, Japan), and the column effluent was monitored at $290 \mathrm{~nm}$ with a photodiode array detector (model SPD-M20A, Shimadzu Corporation). Injection volumes of $100 \mu \mathrm{L}$ were applied to the column with an auto-injector (model Sil-10A $A_{\mathrm{xL}}$, Shimadzu Corporation). Data were collected and 
analyzed with Class-VP software (version 7.1, Shimadzu Corporation).

\section{Assay Validation}

Forced-degradation samples were used to measure the specificity of the assay method. A stock solution of pantoprazole sodium (Sandoz Canada Inc; lot AD6461, expiry October 2010) was prepared by weighing $30 \mathrm{mg}$ of material and dissolving it in $30 \mathrm{~mL}$ of HPLC-grade water. A $10-\mathrm{mL}$ volume of this stock solution was acidified by adjusting the $\mathrm{pH}$ to 4.4 with $0.1 \mathrm{~N}$ hydrochloric acid (Fisher Scientific Ltd; lot 084273). An alkaline degradation sample was prepared by adjusting the $\mathrm{pH}$ of a $10-\mathrm{mL}$ volume of the stock solution to about 12.2 with $5 \mathrm{~N}$ sodium hydroxide (Fisher Scientific Ltd; lot SC6135444). To create an oxidized sample, $0.5 \mathrm{~mL}$ of $30 \%$ hydrogen peroxide (Fisher Scientific Ltd; lot 043211) was combined with $9.5 \mathrm{~mL}$ of stock solution.

At time zero, a portion of the stock solution prepared in HPLC-grade water was diluted 1:10 with mobile phase and was analyzed chromatographically. The acidic and alkaline degradation samples were incubated at $50^{\circ} \mathrm{C}$ in a hot water bath, and the oxidized sample was stored at $23^{\circ} \mathrm{C}$. After 1,5 , $25,73,96,122$, and $1128 \mathrm{~h}$, samples were collected from the degradation solutions, diluted 1:10 with mobile phase, and analyzed chromatographically.

Multiwavelength (220 and $290 \mathrm{~nm}$ ) and ultraviolet (UV) spectral (200-350 nm) analyses were used to determine the purity of all pantoprazole peaks in the degradation samples. Correlation coefficients of the UV spectra were determined by comparing the pantoprazole peak from the degradation samples with the pantoprazole sodium peak in the reference material (Toronto Research Chemicals Inc, Toronto, Ontario; catalogue no. P183000, lot 1-SWM-19-1).

Intraday variation was based on the average area under the curve of 5 replicate samples injected at 3 separate time points on a single day and is reported as the coefficient of variation $(\mathrm{CV})$. The slopes, linear coefficients, and average area under the curve for samples collected on 5 separate days were used to determine the interday variation of the method. Three recovery samples, analyzed in duplicate, obtained on 5 separate days were used to measure the accuracy of the method. The sensitivity of the assay was also determined.

Five known degradation or impurity products of pantoprazole sodium (all obtained from Toronto Research Chemicals Inc) were analyzed for potential interference with the parent compound: pantoprazole $N$-oxide (catalogue no. P183010, lot 11-AZC-121-1), pantoprazole sulphide (catalogue no. P183020, lot 11-SWM-22-1), pantoprazole sulphide $N$-oxide (catalogue no. P183030, lot 11-AZC-115-1), pantoprazole sulphone (catalogue no. P183015, lot 11-AZC-47-1), and pantoprazole sulphone $N$-oxide (catalogue no. P183013, lot 11-AZC-60-1).

\section{Stability Study}

A single 5-mL sample was collected from each container (as described in the "Sample Preparation" section above) immediately after packaging and was placed into a clean glass test tube. These samples were designated as day 0 samples. Subsequently, for containers stored at room temperature, samples were collected on days 2 and 3, whereas containers stored under refrigeration were sampled on days 7, 14, 21, and 28. Each sample was analyzed on the day of collection.

On each analysis day, an accurate stock solution (about $1 \mathrm{mg} / \mathrm{mL}$ ) of pantoprazole sodium was prepared from reference material (Toronto Research Chemicals Inc; catalogue no. P183000, lot 1-SWM-19-1), and a standard curve was prepared by analyzing diluted samples of the stock solution (0.025, 0.05, 0.10, 0.15, and $0.20 \mathrm{mg} / \mathrm{mL}$ with $35 \%$ acetonitrile). The linearity of all standard curves was assessed by least-squares regression analysis. On each day of analysis, sample solutions were diluted either 1:40 (for $4 \mathrm{mg} / \mathrm{mL}$ solutions), $1: 8$ (for $0.8 \mathrm{mg} / \mathrm{mL}$ solutions), or $1: 4$ (for $0.4 \mathrm{mg} / \mathrm{mL}$ solutions) with $35 \%$ acetonitrile and then assayed. An internal standard $(100 \mu \mathrm{L}$ of benzocaine $0.2 \mathrm{mg} / \mathrm{mL})$ was added to each diluted sample solution before analysis. Solutions were considered to be chemically stable if the percentage of initial concentration remained above $90 \%$.

\section{RESULTS}

\section{Physical Compatibility}

No precipitate was apparent when samples were observed under $4 \times$ magnification. The samples were colourless at the time of preparation but developed a slight yellow tinge over the course of the study. This change in colour was more evident in the more concentrated solutions. The $\mathrm{pH}$ changed only slightly over the study period, with a trend toward greater acidity with time (maximum change in $\mathrm{pH}-0.79$; change in mean $\mathrm{pH}$ over time for glass vials, from 9.52 to 9.49 ; for syringes, from 9.59 to 9.46; for PVC bags with D5W diluent, from 8.94 to 8.30 ; and for PVC bags with NS diluent, from 9.26 to 8.47 ).

\section{Chemical Stability HPLC Assay Validation}

The concentration of the acidic degradation sample decreased to about $4 \%$ of the original after $25 \mathrm{~h}$ of heating (Figure 1A). Exposure of pantoprazole to alkaline conditions and heating caused a reduction in concentration of about $14 \%$ after $1128 \mathrm{~h}$ (Figure 1B). After $73 \mathrm{~h}$ exposure to oxidation, only $7.1 \%$ of the original concentration remained (Figure 1C). Figure 1D shows the chromatogram for pantoprazole 0.4 $\mathrm{mg} / \mathrm{mL}$ in D5W after 28 days of storage under refrigeration with protection from light. Two new minor peaks appeared 

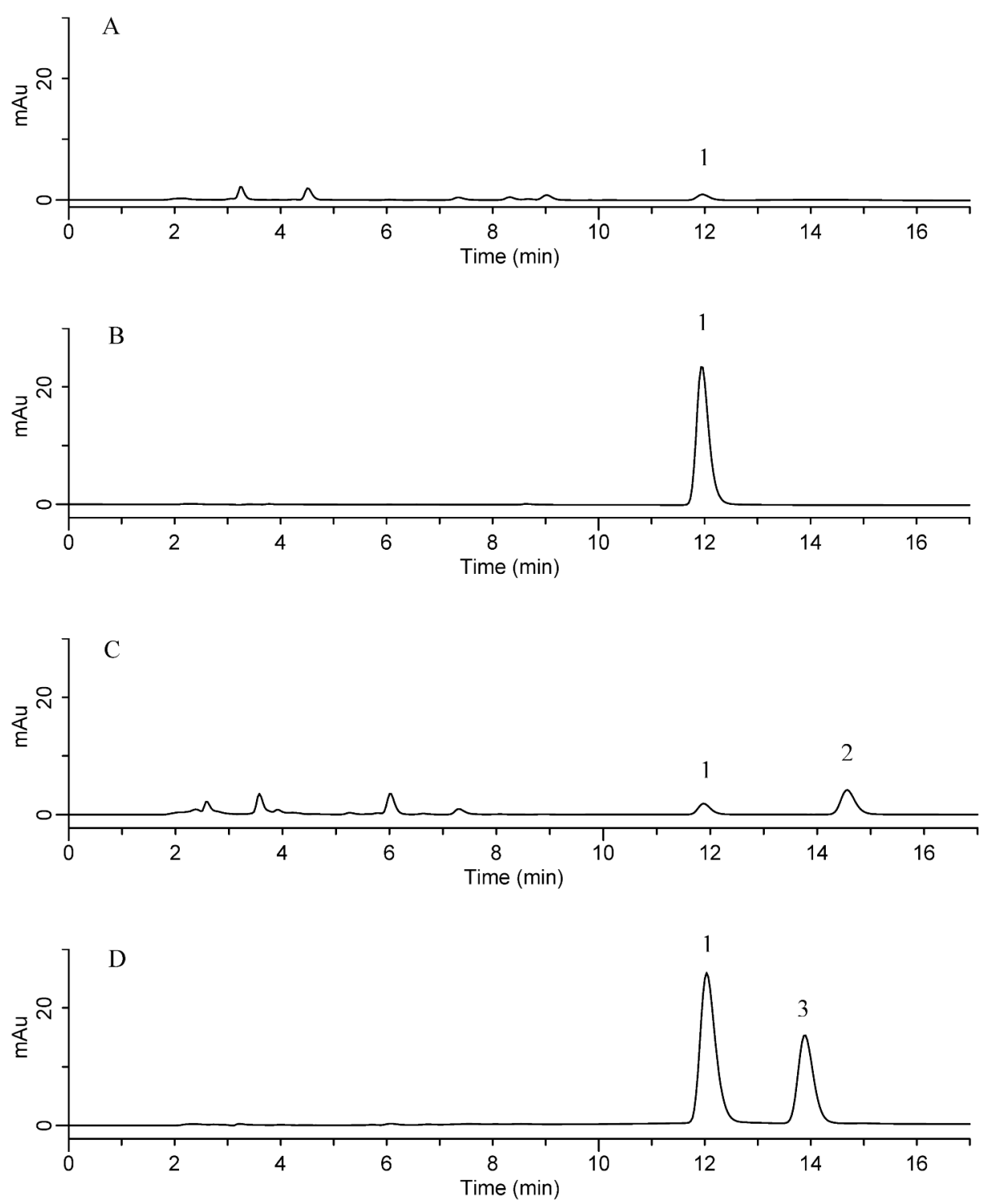

Figure 1. A: Chromatogram of an acid-degraded sample of pantoprazole sodium ( $\mathrm{pH}$ adjusted to 4.4 ) after heating for $25 \mathrm{~h}$. B: Chromatogram of an alkaline-degraded sample of pantoprazole sodium (pH adjusted to 12.2) after heating for $1128 \mathrm{~h}$. C: Chromatogram of an oxidized sample of pantoprazole sodium after $73 \mathrm{~h}$ at room temperature. D: Chromatogram of pantoprazole sodium diluted to $0.4 \mathrm{mg} / \mathrm{mL}$ in $5 \%$ dextrose in water after refrigeration for 28 days with protection from light. Key to numbering of peaks: peak 1 is pantoprazole sodium, peak 2 is a degradation product, and peak 3 is the internal standard. $A U=$ absorbance units.

during the 28 days of storage. None of the degradation peaks interfered with the parent peak or the peak for the internal standard. The purity of the pantoprazole peaks in the degradation samples was confirmed by multiwavelength and UV spectral analysis. The correlation coefficient was greater than 0.990 for spectral comparison of the parent compound with the reference material.

The intraday CV of $1.30 \%$ was based on a comparison of area ratios of pantoprazole sodium to internal standard determined at 0,5 , and $24 \mathrm{~h}$. The interday CVs (for samples collected on 5 separate days) were $2.25 \%$ for slope, $0.05 \%$ for linear coefficients, and $1.19 \%$ for average area. The average recovery \pm standard deviation from samples of known concentration was $100.3 \% \pm 1.2 \%$. The calculated sensitivity of the assay for pantoprazole sodium was $10.3 \mathrm{ng}$.

None of the peaks of the known degradation and impurity compounds interfered with the peak for pantoprazole sodium. The elution times for these peaks were $6.0 \mathrm{~min}$ for pantoprazole $\mathrm{N}$-oxide, $2.6 \mathrm{~min}$ for pantoprazole sulphide, $11.5 \mathrm{~min}$ for pantoprazole sulphide $N$-oxide, $15.8 \mathrm{~min}$ for pantoprazole 
sulphone, and $6.9 \mathrm{~min}$ for pantoprazole sulphone $N$-oxide, whereas pantoprazole sodium eluted at $12.1 \mathrm{~min}$ and the internal standard at $14.0 \mathrm{~min}$.

\section{Stability Study}

The results of the determination of chemical stability of pantoprazole sodium are summarized in Tables 1 to 4 . Pantoprazole sodium $4 \mathrm{mg} / \mathrm{mL}$ stored in glass vials at room temperature with exposure to light was stable for 3 days (Table 1). Pantoprazole sodium $4 \mathrm{mg} / \mathrm{mL}$ stored in polypropylene syringes under refrigeration with protection from light was stable for 28 days (Table 2). Pantoprazole sodium prepared in D5W at $0.4 \mathrm{mg} / \mathrm{mL}$ and stored in minibags was stable for 2 days at room temperature with exposure to light or 14 days under refrigeration with protection from light (Table 3). The more concentrated solution of pantoprazole sodium prepared in D5W $(0.8 \mathrm{mg} / \mathrm{mL})$ and stored in minibags was stable for 3 days at room temperature with exposure to light or 28 days under refrigeration with protection from light. Pantoprazole sodium diluted in NS at 0.4 or $0.8 \mathrm{mg} / \mathrm{mL}$ and stored in minibags was stable for 3 days at room temperature with exposure to light or 28 days under refrigeration with protection from light (Table 4). As the samples of pantoprazole sodium degraded during the study, 2 new peaks appeared in the chromatograms, with retention times similar to those of 2 peaks in the samples created by forced degradation (Figure 1D).

\section{DISCUSSION}

To the author's knowledge, this is the first reported study of the stability of pantoprazole sodium stored in glass vials, although one manufacturer ${ }^{5}$ recommends using the reconstituted solution and any further dilutions within $6 \mathrm{~h}$ of initial puncture of the vial stopper.

Walker and others ${ }^{1}$ investigated the stability of pantoprazole sodium, in a formulation containing EDTA, when further diluted with either D5W or NS and packaged in PVC bags.

Table 1. Stability of Pantoprazole Sodium $4 \mathrm{mg} / \mathrm{mL}$ in $\mathbf{0 . 9 \%}$ Sodium Chloride after Storage in Glass Vials at Room Temperature $\left(20^{\circ} \mathrm{C}\right.$ to $\left.25^{\circ} \mathrm{C}\right)$ with Exposure to Light

\begin{tabular}{lc} 
Study Day & $\begin{array}{c}\% \text { of Initial Concentration } \\
\text { Remaining (Mean } \pm \text { SD)* }\end{array}$ \\
\hline $\begin{array}{l}\text { Initial concentration } \\
(\mathrm{mg} / \mathrm{mL})\end{array}$ & $4.55 \pm 0.09$ \\
Day 2 & $101.7 \pm 1.2$ \\
Day 3 & $95.6 \pm 0.8$
\end{tabular}

$\mathrm{SD}=$ standard deviation.

*Except as indicated otherwise.

†Mean \pm SD $(n=6)$.
These authors suggested a shorter expiry timeframe than is reported here, because they allowed the solutions to be stored at room temperature for a certain amount of time after refrigerated storage, which led to faster degradation. In another study, ${ }^{2}$ the same authors examined the stability of EDTA-free pantoprazole sodium obtained from another manufacturer and found that solutions diluted to 0.4 and $0.8 \mathrm{mg} / \mathrm{mL}$ in NS were stable for $48 \mathrm{~h}$ at $23^{\circ} \mathrm{C}$ or 14 days at $4^{\circ} \mathrm{C}$. In that study, the concentration remained at $100 \%$ after 14 days, which supports the finding reported here that both concentrations of pantoprazole prepared in NS were stable for 28 days at $5^{\circ} \mathrm{C}$. Carpenter and others ${ }^{3}$ found that an EDTAfree product was stable for $48 \mathrm{~h}$ when diluted to $0.4 \mathrm{mg} / \mathrm{mL}$ with either D5W or NS and stored at $22^{\circ} \mathrm{C}$. The duration of stability of $0.4 \mathrm{mg} / \mathrm{mL}$ solutions prepared in $\mathrm{D} 5 \mathrm{~W}$ was the same in that study and the one reported here (2 days at room temperature); the duration of stability of solutions prepared in NS was 1 day longer in the current study (3 days at room temperature) than in the earlier study, at which point about $94 \%$ of the original concentration remained. In the study by Johnson, ${ }^{4}$ the concentration of pantoprazole sodium in polypropylene syringes was greater than $99 \%$ of the original concentration after 4 days of storage at either $3^{\circ} \mathrm{C}$ to $5^{\circ} \mathrm{C}$ or $23^{\circ} \mathrm{C}$ to $25^{\circ} \mathrm{C}$. In the study reported here, similar solutions were stable for 28 days when stored under refrigeration.

In this study, pantoprazole seemed to be more stable in NS than in D5W at both concentrations $(0.4$ and $0.8 \mathrm{mg} / \mathrm{mL})$. Both Walker and others ${ }^{1}$ and Carpenter and others ${ }^{3}$ observed the same trend. In both the study by Walker and others ${ }^{1}$ and the study reported here, stability was concentration-dependent, with more concentrated solutions being more stable at both storage temperatures.

All solutions were initially colourless when viewed under $4 \times$ magnification against a white background; however, over time the solutions developed a slight yellow shade, which was

\section{Table 2. Stability of Pantoprazole Sodium $4 \mathrm{mg} / \mathrm{mL}$ in $\mathbf{0 . 9 \%}$ Sodium Chloride after Storage in Polypropylene Syringes under Refrigeration $\left(2^{\circ} \mathrm{C}\right.$ to $\left.8^{\circ} \mathrm{C}\right)$ with Protection from Light}

\begin{tabular}{lc} 
Study Day & $\begin{array}{c}\text { \% of Initial Concentration } \\
\text { Remaining (Mean } \pm \text { SD)* }\end{array}$ \\
\hline $\begin{array}{l}\text { Initial concentration } \\
(\mathrm{mg} / \mathrm{mL})\end{array}$ & $4.28 \pm 0.07$ \\
Day 7 & $98.8 \pm 0.6$ \\
Day 14 & $102.2 \pm 1.3$ \\
Day 21 & $99.3 \pm 1.0$ \\
Day 28 & $101.9 \pm 0.9$ \\
\hline
\end{tabular}

SD = standard deviation.

*Except as indicated otherwise.

tMean \pm SD $(n=6)$. 
Table 3. Stability of Pantoprazole Sodium in 5\% Dextrose in Water after Storage in Polyvinylchloride Minibags

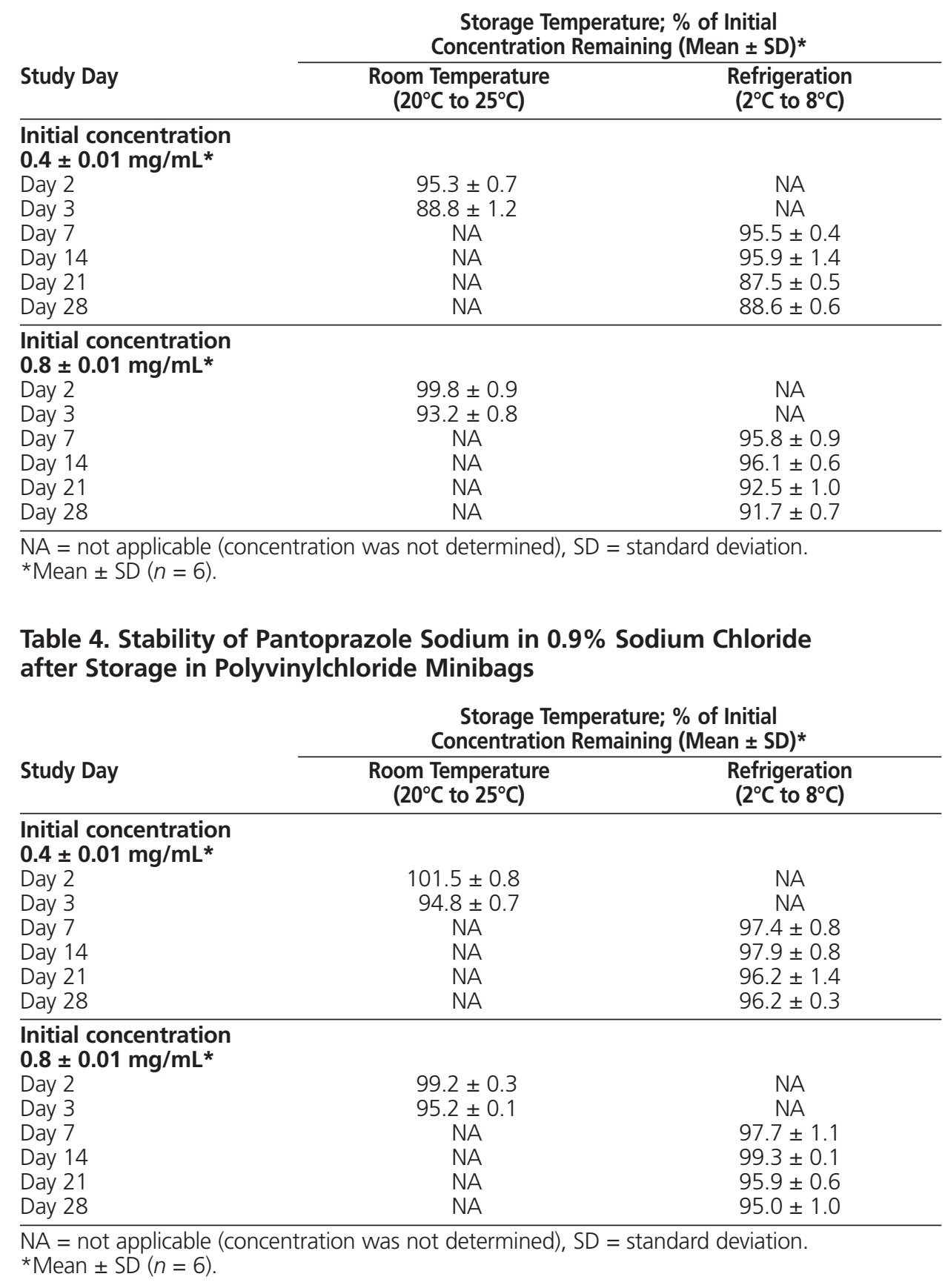

more apparent in the more concentrated solutions. Johnson ${ }^{4}$ reported a similar finding. Neither study found any association between the colour change and a decrease in concentration of the pantoprazole.

\section{CONCLUSIONS}

Pantoprazole sodium (Sandoz Canada Inc, $4 \mathrm{mg} / \mathrm{mL}$ ) stored in glass vials was stable for 3 days at room temperature $\left(20^{\circ} \mathrm{C}\right.$ to $\left.25^{\circ} \mathrm{C}\right)$ with exposure to light. When packaged in polypropylene syringes, pantoprazole $(4 \mathrm{mg} / \mathrm{mL})$ was stable for 28 days with storage under refrigeration $\left(2^{\circ} \mathrm{C}\right.$ to $\left.8^{\circ} \mathrm{C}\right)$ with protection from light. Pantoprazole diluted to $0.4 \mathrm{mg} / \mathrm{mL}$ in D5W and stored in PVC minibags was stable for 2 days at room temperature $\left(20^{\circ} \mathrm{C}\right.$ to $\left.25^{\circ} \mathrm{C}\right)$ with exposure to light or 14 days under refrigeration $\left(2^{\circ} \mathrm{C}\right.$ to $\left.8^{\circ} \mathrm{C}\right)$ with protection from light. Pantoprazole $0.8 \mathrm{mg} / \mathrm{mL}$ in $\mathrm{D} 5 \mathrm{~W}$ had beyond-use dates of 3 days at room temperature $\left(20^{\circ} \mathrm{C}\right.$ to $\left.25^{\circ} \mathrm{C}\right)$ with exposure to light and 28 days under refrigeration $\left(2^{\circ} \mathrm{C}\right.$ to $\left.8^{\circ} \mathrm{C}\right)$ with 
protection from light. Pantoprazole diluted to 0.4 and $0.8 \mathrm{mg} / \mathrm{mL}$ in NS and stored in PVC minibags was stable for 3 days at room temperature $\left(20^{\circ} \mathrm{C}\right.$ to $\left.25^{\circ} \mathrm{C}\right)$ with exposure to light or 28 days under refrigeration $\left(2^{\circ} \mathrm{C}\right.$ to $\left.8^{\circ} \mathrm{C}\right)$ with protection from light.

Institutions should base the final expiry date for pantoprazole on their own results for sterility testing and aseptic validation, as well as the chemical stability of the drug.

\section{References}

1. Walker S, Iazzetta J, Law S. Extended stability of pantoprazole for injection in $0.9 \%$ sodium chloride or $5 \%$ dextrose at $4^{\circ} \mathrm{C}$ and $23^{\circ} \mathrm{C}$. Can J Hosp Pharm 2009;62(2):135-141.

2. Walker SE, Iazzetta J, Law S. Stability of pantoprazole in $0.9 \%$ sodium chloride (NS) at $4^{\circ} \mathrm{C}$ and room temperature $\left(24^{\circ} \mathrm{C}\right)$ [abstract]. Can J Hosp Pharm 2005;58 Suppl 2:S34.

3. Carpenter JF, McNulty MA, Dusci LJ, Ilett KF. Stability of omeprazole sodium and pantoprazole sodium diluted for intravenous infusion. $J$ Pharm Tech 2006;22:95-98.

4. Johnson CE. Stability of pantoprazole in $0.9 \%$ sodium chloride injection in polypropylene syringes. Am J Health Syst Pharm 2005;62(22): 2410-2412.
5. Pantoprazole sodium for injection [product monograph]. Boucherville (QC): Sandoz Canada Inc; 2008 Feb 17.

6. Pantoprazole sodium for injection [product monograph]. Montreal (QC): Pharmascience Inc; 2009 May 5.

Ronald F Donnelly, MSc(Chem), BSc(Pharm), is Product Development Pharmacist with the Department of Pharmaceutical Sciences, The Ottawa Hospital (Civic Campus), Ottawa, Ontario.

Address correspondence to:

Ronald F Donnelly

Department of Pharmaceutical Sciences

The Ottawa Hospital

1053 Carling Avenue

Ottawa ON K1Y 4E9

e-mail: rdonnelly@ottawahospital.on.ca

Acknowledgement

This project was funded by an unrestricted research grant from Sandoz Canada.

\section{CJHP Subscriptions 20 I I / Abonnements au JCPH 20 I I}

CSHP has introduced both Print and Print + Online pricing models for CJHP subscriptions. Print + Online $\mathrm{CJHP}$ is included as a benefit of CSHP membership. All prices are in Canadian funds.

La SCPH a établi une grille tarifaire pour l'abonnement à la copie imprimée du JCPH seulement et pour l'abonnement à la fois aux copies imprimée et électronique du journal. L'abonnement combiné est inclus dans les droits d'adhésion à la SCPH. Tous les prix sont en dollars canadiens.

\begin{tabular}{|l|l|l|}
\hline $\begin{array}{l}\text { Subscriber group / Groupe } \\
\text { d'abonnés }\end{array}$ & $\begin{array}{l}\text { Print only / Texte imprimé } \\
\text { seulement }\end{array}$ & $\begin{array}{l}\text { New! Print + Online copy } \\
\text { Nouveau! Texte imprimé } \\
\text { et exemplaire électronique }\end{array}$ \\
\hline $\begin{array}{l}\text { Nonmembers within Canada / } \\
\text { Non-membres au Canada }\end{array}$ & $\begin{array}{l}\$ 110.00 \text { per year, plus GST or HST } \\
110,00 \$ \text { par an, plus TPS ou TVH }\end{array}$ & $\begin{array}{l}\$ 150.00 \text { per year, plus GST or HST } \\
150,00 \$ \text { par an, plus TPS ou TVH }\end{array}$ \\
\hline USA / É.-U. & $\begin{array}{l}\$ 140.00 \text { per year } \\
140,00 \$ \text { par an }\end{array}$ & $\begin{array}{l}\$ 180.00 \text { per year } \\
180,00 \$ \text { par an }\end{array}$ \\
\hline Foreign / Étranger & $\$ 180.00$ per year & $\$ 220.00$ per year \\
& $180,00 \$$ par an & $220,00 \$$ par an \\
\hline
\end{tabular}

More details can be found at www.cjhp-online.ca. If you would like to purchase a subscription, please fill out our CJHP 2011 Subscription Application Form, which can be found on the CJPH website. Please direct any comments or questions to Colleen Drake, Publications Administrator,at cdrake@cshp.ca.

Des détails supplémentaires sont fournis à www.cihp-online.ca. Si vous désirez vous abonner, veuillez remplir le formulaire d'abonnement au JCPH 2011. Vous pouvez l'obtenir en visitant le site Web du JCPH. Pour tout commentaire ou toute question, veuillez vous adresser à Colleen Drake, agente des publications, en écrivant à cdrake@cshp.ca. 